\title{
KEANEKARAGAMAN DAN PEMANFAATAN TUMBUHAN BAWAH PADA SISTEM AGROFORESTRI DI PERBUKITAN MENOREH, KABUPATEN KULON PROGO (Diversity and Untilization of Understorey in Agroforestry System of Menoreh Hill, Kulon Progo Regency)
}

\author{
Etik Erna Wati Hadi $^{*}$, Siti Muslimah Widyastuti ${ }^{2}$ dan Subagus Wahyuono ${ }^{3}$ \\ ${ }^{1}$ Balai Penelitian Kehutanan Palembang, Jl. Kol. H. Burlian km 6,5 Puntikayu, Palembang 30153. \\ ${ }^{2}$ Fakultas Kehutanan, Universitas Gadjah Mada, Jl. Agro No. 1 Bulaksumur, Yogyakarta 55281. \\ ${ }^{3}$ Fakultas Farmasi, Universitas Gadjah Mada, Sekip Utara, Bulaksumur, Yogyakarta 55281. \\ *Penulis korespondensi. Tel: 087897237547. Email: etik_imkho@yahoo.co.id.
}

Diterima: 12 Juni 2015

Disetujui: 1 Februari 2016

\begin{abstract}
Abstrak
Agroforestri yang diadopsi masyarakat dalam bentuk pekarangan dan tegalan menyimpan potensi keanekaragaman jenis tumbuhan bawah yang diduga memiliki berbagai manfaat bagi masyarakat. Penelitian ini bertujuan untuk mengetahui keanekaragaman jenis tumbuhan bawah pada sistem agroforestri dan pemanfaatannya oleh masyarakat di perbukitan Menoreh. Metode penelitian yang digunakan adalah metode survey dengan melakukan inventarisasi jenis tumbuhan bawah serta wawancara dengan tokoh masyarakat tentang pemanfaatan tumbuhan bawah yang selama ini dilakukan. Penelitian dilakukan dalam kurun waktu November 2012 sampai dengan April 2013, berlokasi di perbukitan Menoreh Kabupaten Kulon Progo yang terbagi dalam 3 zona berdasarkan ketinggian tempat. Berdasarkan hasil penelitian, keanekaragaman jenis tumbuhan bawah cenderung semakin tinggi pada lokasi yang lebih tinggi. Jenis tumbuhan bawah di pekarangan lebih banyak dibandingkan di tegalan pada semua zona ketinggian tempat. Tumbuhan bawah yang berhasil teridentifikasi sebanyak 41 jenis, 28 jenis di antaranya dimanfaatkan masyarakat sebagai bahan obat, antara lain untuk penyakit kulit, demam dan beberapa penyakit degeneratif seperti hipertensi, kanker, asam urat, asma dan sebagainya. Cara pemanfaatannya dengan dimakan langsung (dilalap), direbus, dibuat teh dan diambil sari patinya. Beberapa jenis tumbuhan bawah telah dimanfaatkan masyarakat secara tradisional sebagai bahan obat dan dibudidayakan sebagai sumber penghasilan tambahan.
\end{abstract}

Kata kunci: agroforestri, bahan obat, keanekaragaman jenis, penghasilan tambahan, tumbuhan bawah.

\begin{abstract}
Agroforestry adopted community in the form of homegardens and drylands holds the potential diversity of plants below that allegedly have various benefits for the community. This study aims to determine the diversity of plant species under the agroforestry system and its utilization by the community in the hills Menoreh. The method used is a survey method to conduct an inventory of understorey species and interviews with community leaders on the use of understorey has been done. The study was conducted in the period November 2012 to April 2013, located in the hills Menoreh, Kulon Progo regency is divided into three zones based on altitude. Based on this research, the diversity of understorey species the higher tends to a higher location. Understorey species in the homegardens more than in drylands at all altitude zones. Understorey species which were identified as many as 41 species, 28 species of which society is used as medicine, such as for skin diseases, fever and some degenerative diseases such as hypertension, cancer, gout, asthma and so on. To utilization to be eaten immediately (engulfed), stewed, made tea and juice taken the extract. Understorey species have been used traditionally as a community drug substance and cultivated as a source of additional income.
\end{abstract}

Keywords: agroforestry, medicinal materials, biodiversity, additional income understorey.

\section{PENDAHULUAN}

Tumbuhan bawah memiliki peran sangat penting dalam ekosistem, antara lain dalam siklus hara, pengurangan erosi, peningkatan infiltrasi, sebagai sumber plasma nutfah, sumber obat-obatan, pakan ternak dan satwa hutan, serta manfaat lainnya yang belum diketahui (Abdiyani, 2008). Peran dalam siklus hara tumbuhan bawah dijadikan sebagai indikator kesuburan tanah dan penghasil serasah dalam meningkatkan kesuburan tanah, dalam mengurangi erosi keberadaan tumbuhan bawah dapat menahan pukulan air hujan dan aliran permukaan (Hilwan dkk., 2013). Keanekaragaman jenis tumbuhan bawah yang terdapat di suatu tempat dipengaruhi oleh beberapa faktor, di antaranya ketinggian tempat yang mempengaruhi curah hujan dan suhu udara sehingga menghasilkan kondisi tempat yang berbeda, intensitas naungan (Djufri, 2011), dan pH tanah (Hilwan dkk., 2013).

Tumbuhan bawah memiliki potensi sebagai bahan obat tradisional, pemanfaatannya dilakukan 
secara turun temurun. Di Indonesia terdapat \pm 300 kelompok etnis yang memanfaatkan tumbuhan dalam kehidupan mereka, seperti untuk obat-obatan, peralatan rumah tangga, kerajinan, dan upacara adat (Karina, 2014). Pemanfaatan tumbuhan bawah sebagai obat telah banyak dilakukan oleh masyarakat terutama masyarakat tradisional yang tinggal jauh dari layanan kesehatan. Etnobotani tumbuhan obat merupakan salah satu bentuk interaksi antara masyarakat dengan lingkungan alamnya. Kajian etnobotani menekankan pada keterkaitan antara budaya masyarakat dengan sumberdaya tumbuhan, baik secara langsung maupun tidak langsung (Setiawan dan Qiptiyah, 2014). Dokumentasi pengetahuan lokal masyarakat dalam memanfaatkan sumberdaya tumbuhan akan sangat membantu menjaga kelestarian keanekaragaman hayati dan usaha domestikasi tanaman obat yang bernilai penting (Kandari dkk., 2012).

Agroforestri merupakan suatu sistem pengelolaan lahan yang ditawarkan untuk mengatasi masalah yang timbul akibat alih guna lahan dan untuk mengatasi masalah pangan. Bentuk agroforestri secara umum mencakup kebun campuran, tegalan berpohon, ladang, lahan bera (belukar), kebun pekarangan, hutan tanaman rakyat yang lebih kaya jenis. Masyarakat di pulau Jawa, terutama di perbukitan Menoreh memiliki pekarangan dan tegalan sejak zaman dahulu. Penggunaan lahan di perbukitan Menoreh didominasi untuk kebun/tegalan sebesar 37,49\% dan pekarangan sebesar $21,33 \%$ dari luas total wilayah

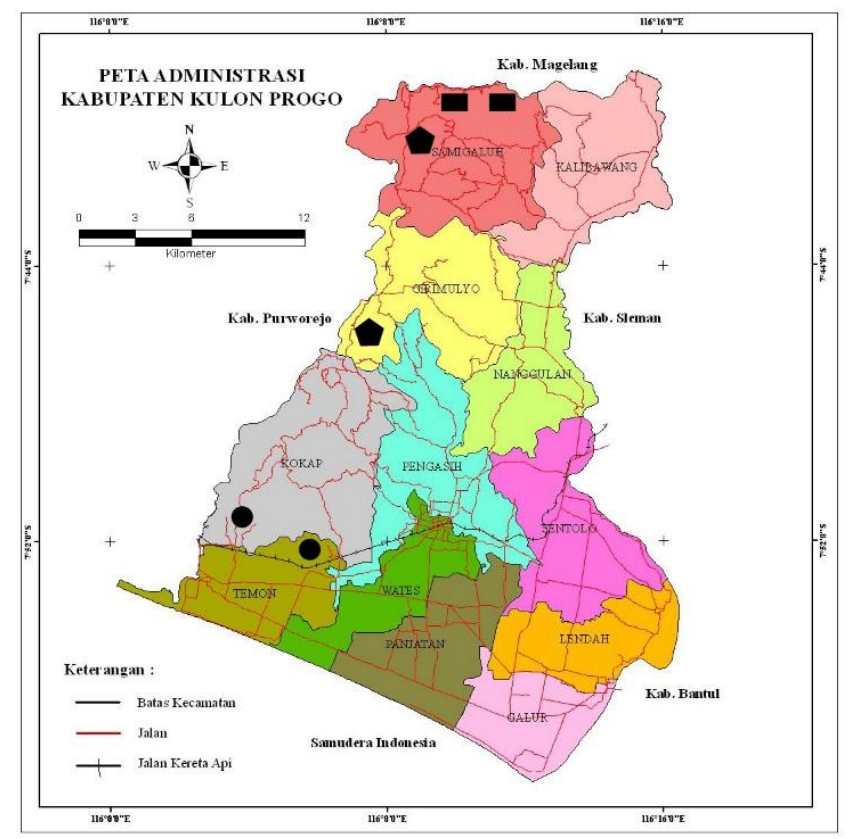

Keterangan:

Zona 1 Zona 2 Zona 3

Gambar 1. Peta wilayah Kabupaten Kulon Progo (Sumber: Bappeda Kabupaten Kulon Progo, 2009).
(Hadi, 2013). Di beberapa daerah terutama di pedesaan pengembangan pekarangan umumnya diarahkan untuk memenuhi sumber pangan seharihari, sehingga sering disebut sebagai lumbung hidup atau warung hidup (Rahayu dan Prawiroatmodjo, 2005).

Berdasarkan hal tersebut, penelitian ini bertujuan untuk mengetahui keanekaragaman jenis tumbuhan bawah berdasarkan bentuk pengelolaan lahan (sistem agroforestri pekarangan dan tegalan), dan mendokumentasikan informasi pemanfaatan tumbuhan bawah sebagai bahan obat tradisional oleh masyarakat di perbukitan Menoreh Kabupaten Kulon Progo. Informasi yang diperoleh dari penelitian ini dapat dimanfaatkan untuk mengembangkan sistem agroforestri pekarangan dan tegalan melalui kegiatan diversifikasi dengan budidaya tanaman obat yang pada akhirnya diharapkan menambah sumber pendapatan masyarakat.

\section{METODE PENELITIAN}

\section{Waktu dan Lokasi}

Penelitian dilakukan pada November 2012 sampai dengan April 2013. Lokasi penelitian di wilayah Kabupaten Kulon Progo, Provinsi DIY (Gambar 1). Lokasi penelitian di 3 (tiga) zona ketinggian tempat yang dinilai memberikan pengaruh pada kondisi tempat tumbuh. Zona tersebut terbagi dalam zona 1 (ketinggian $<300 \mathrm{mdpl}$ antara lain desa Kulur, Kecamatan Temon; desa Hargowilis, Kecamatan Kokap), zona 2 (ketinggian 300-600 mdpl (Desa Gerbosari, Kecamatan Samigaluh; Desa Jatimulyo, Kecamatan Girimulyo) dan zona 3 (ketinggian> $600 \mathrm{mdpl}$ (Desa Madigondo, Kecamatan Samigaluh; Desa Keceme, Kecamatan Samigaluh). Di setiap zona diambil lahan dengan bentuk pengelolaan pekarangan dan tegalan, kemudian dilakukan inventarisasi jenis tumbuhan bawah serta menggali informasi pemanfaatannya oleh masyarakat setempat.

\section{Bahan dan Alat}

Bahan yang digunakan dalam inventarisasi tumbuhan bawah adalah tumbuhan bawah yang terdapat di pekarangan dan tegalan milik masyarakat yang mewakili 6 (enam) lokasi di 3 (tiga) zona ketinggian tempat. Peralatan yang digunakan dalam penelitian ini adalah alat untuk pembuatan plot inventarisasi tumbuhan bawah, lux meter, GPS, dan alat dokumentasi.

\section{Pengambilan Data}

Data vegetasi terdiri dari data jenis pohon dan tumbuhan bawah. Pengambilan data dilakukan dengan cara inventarisasi dan identifikasi jenis 


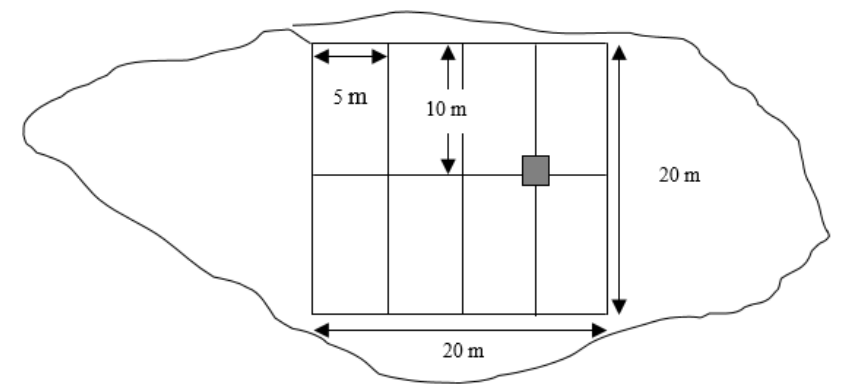

Gambar 2. Pembuatan dan peletakan petak contoh.

tumbuhan bawah dengan membuat petak contoh (gambar 2) di setiap lokasi penelitian. Metode pembuatan petak dengan membuat plot di setiap lokasi dengan ukuran 20 x 20 meter untuk mengetahui jenis tanaman berkayu (pancangpohon) dan di dalamnya dibuat plot inventarisasi jenis tumbuhan bawah berukuran $1 \times 1$ meter. Peletakan petak contoh menggunakan metode sampling beraturan/pola kisi. Petak contoh diletakkan pada pertemuan antara garis datar dan garis tegak. Jarak antar jalur 5 meter dan jarak antar plot dalam jalur yang sama 10 meter (Modifikasi dari Tjitrosoedirdjo dkk., 1984).

\section{Analisis Data}

Tumbuhan bawah hasil inventarisasi kemudian diidentifikasi untuk mengetahui nama lokal dan ilmiahnya. Komposisi tumbuhan bawah dapat dilihat berdasarkan indeks nilai penting (INP), keanekaragaman jenis dilihat berdasarkan indeks keanekaragaman Shannon dan untuk melihat kesamaan populasi tumbuhan bawah di beberapa tempat menggunakan indeks similaritas yang digunakan oleh Dombois dan Ellenberg. Berikut ini rumus-rumus untuk perhitungan:

a. Dominasi jenis tumbuhan bawah (INP)

INP digunakan untuk menetapkan dominansi jenis terhadap jenis yang lain.

$$
\text { Kerapatan }(\mathrm{K}) \quad=\frac{\text { Jumlah individu }}{\text { Luas petak contoh }}
$$

Kerapatan Relatif $(\mathrm{KR})=\frac{\text { Kerapatan setiap jenis }}{\text { Kerapatan seluruh jenis }} \times 100 \%$

Frekuensi $(\mathrm{F}) \quad=\frac{\text { Jumlah petak ditemui jenis tertentu }}{\text { Jumlah seluruh petak }}$

Frekuensi Relatif $(F R)=\frac{\text { Frekuensi setiap jenis }}{\text { Frekuensi seluruh jenis }} \times 100 \%$

$\mathrm{INP}=\mathrm{KR}+\mathrm{FR}$

b. Keanekaragam jenis tumbuhan bawah

$\mathrm{H}^{\prime}=-\sum_{i=1}^{n}\left[\frac{\mathrm{ni}}{\mathrm{N}} \ln \frac{\mathrm{ni}}{\mathrm{N}}\right]$

di mana: $H^{\prime}=$ indeks keanekaragaman jenis

ni $=$ jumlah individu tiap jenis

$\mathrm{N}=$ total individu seluruh jenis

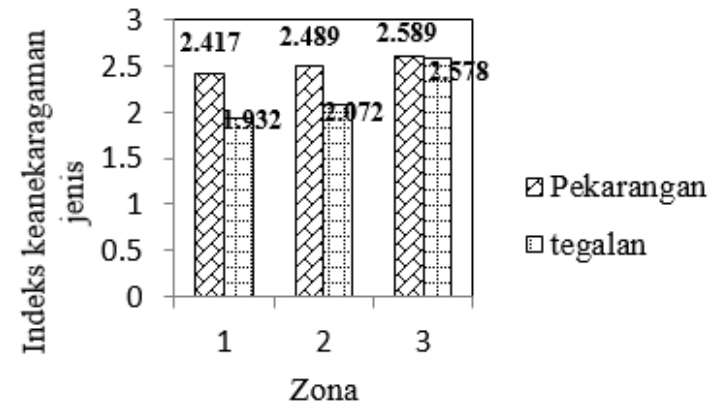

Gambar 3. Indeks keanekaragaman jenis tumbuhan bawah pada sistem agroforestri pekarangan dan tegalan

Dengan kriteria $\mathrm{H}^{\prime}<1$ memiliki keanekaragaman jenis rendah, $1<\mathrm{H}^{\prime}<3$ keanekaragaman jenis sedang dan $\mathrm{H}^{\prime}>3$ memiliki keanekaragaman jenis tinggi.

c. Indeks similaritas (IS)

IS $=\frac{c}{(a+b) / 2}$

di mana: $\quad$ IS $=$ indeks similaritas

$\mathrm{a}=$ jumlah jenis yang ditemukan di komunitas a

$\mathrm{b}=$ jumlah jenis yang ditemukan di komunitas $\mathrm{b}$

$\mathrm{c}=$ jumlah jenis yang ditemukan di komunitas a dan b

Nilai IS berkisar 0-100\%, dikelompokkan dalam 4 kelompok (Lubis, 2009) yaitu sangat mirip (IS $\leq 25 \%$ ), tidak mirip (IS 25-50\%), mirip (50-75\%) dan sangat mirip ( $\geq 75 \%)$.

\section{HASIL DAN PEMBAHASAN}

\section{Keanekaragaman Jenis Tumbuhan Bawah}

Agroforestri banyak diadopsi oleh petani di Indonesia karena merupakan teknik penggunaan lahan yang sangat cocok untuk dilakukan di lahan yang sempit (pekarangan) dan tegalan (lahan kering) (Kusumedi dan Jariyah, 2010). Hasil yang didapatkan berkelanjutan, produk jangka pendek berupa produk non kayu (perkebunan/pertanian) dan produk kayu sebagai hasil jangka panjang. Tumbuhan bawah merupakan salah satu komponen penyusun ekosistem pekarangan dan tegalan di perbukitan Menoreh. Di pekarangan dan tegalan terdiri dari beberapa jenis yaitu pohon, perdu, liana, tanaman semusim dan jenis rumput-rumputan. Hasil penelitian menunjukkan terdapat kecenderungan penambahan jumlah jenis tumbuhan bawah dengan bertambahnya ketinggian tempat (Gambar 3). Sejalan dengan hal tersebut, Tjitrosoedirdjo dkk. (1984) menyebutkan bahwa tumbuhan bawah pada dataran tinggi cenderung memiliki keanekaragaman jenis yang lebih banyak, sedangkan kelimpahan individunya sedikit demikian sebaliknya. 
Keanekaragaman jenis tumbuhan di suatu tempat dipengaruhi oleh beberapa faktor, baik faktor dalam maupun faktor luar. Kurniawan dan Parikesit (2008) menyatakan bahwa kehadiran suatu jenis tumbuhan di tempat tertentu dipengaruhi faktor lingkungan yang saling terkait satu dengan lainnya antara lain iklim, edafik (tanah), topografi dan biotik. Persebaran jenis secara tidak langsung dipengaruhi oleh interaksi antara vegetasi itu sendiri, suhu, kelembaban udara, fisik-kimia tanah yang menghasilkan kondisi lingkungan tertentu yang menyebabkan hadir atau tidaknya suatu spesies dan tersebar dengan tingkat adaptasi yang beragam (Nahdi dkk, 2014). Di samping kondisi habitat, keanekaragaman jenis dalam komunitas dipengaruhi oleh adanya ganguan, baik secara alami maupun akibat aktivitas manusia. Indeks keanekaragaman tumbuhan bawah di semua lokasi penelitian termasuk dalam kategori sedang $\left(1 \leq \mathrm{H}^{\prime} \leq 3\right)$, artinya secara ekologi vegetasi tumbuhan bawah berada dalam kondisi relatif stabil. Tekanan ekologi akibat aktivitas manusia tidak memberikan pengaruh terhadap kondisi lingkungan, sehingga jenis yang mampu tumbuh cukup banyak. Nilai indeks keanekaragaman rendah dapat menunjukkan adanya tekanan ekologi yang tinggi. Tekanan ekologi bisa berasal dari faktor biotik (persaingan antar individu tumbuhan untuk setiap tingkatan) atau faktor abiotik. Tekanan ekologi yang tinggi menyebabkan tidak semua jenis tumbuhan dapat bertahan hidup di suatu lingkungan.

Keanekaragaman jenis berdasarkan nilai H' antara pekarangan dan tegalan menunjukkan keanekaragaman jenis di pekarangan lebih tinggi. Hal ini dilakukan masyarakat dalam memenuhi kebutuhan hidup seperti sayuran, bumbu, tanaman obat dan lain sebagainya. Tanaman pekarangan memiliki struktur yang berbeda dari suatu tempat dengan tempat lain. Faktor yang dapat mempengaruhi struktur dan perkembangan pekarangan adalah faktor iklim, edafik dan sosial budaya masyarakat setempat (Rina dkk., 2012). Bagi masyarakat Jawa, fungsi pekarangan untuk menghasilkan produk yang mengandung nutrisi tinggi (protein, vitamin dan mineral), tanaman obat dan bambu, kayu bakar, kadang-kadang menghasilkan pakan ternak dan kayu bangunan (Kumar dan Nair, 2004). Keanekaragaman jenis tumbuhan bawah di tegalan lebih rendah dibandingkan di pekarangan, dikarenakan rerata intensitas naungan di tegalan lebih tinggi. Tegalan umumnya ditanami jenis kayu-kayuan dan strukturnya menyerupai hutan. Fakta tersebut sesuai dengan hasil penelitian Djufri (2010) yang menyatakan indeks keanekaragaman jenis pada daerah yang terbuka cenderung lebih tinggi dibandingkan dengan daerah yang ternaungi. Jenis yang tumbuh di tegalan umumnya adalah rumput dan tumbuhan liar akibat kurangnya intensitas pemeliharaan.

Tumbuhan bawah dapat ditemukan di berbagai zona ketinggian tempat, data sebaran berdasarkan zona ketinggian tempat terdapat dalam Tabel 1 . Indeks Nilai Penting (INP) digunakan untuk mengetahui jenis-jenis yang mendominasi dalam suatu komunitas. Berdasarkan INP, jenis tumbuhan bawah yang mendominasi di pekarangan maupun tegalan zona 1, 2 dan 3 adalah Curcuma mangga (temu mangga).

Beberapa jenis dari famili Zingiberaceae banyak ditemukan pada lokasi penelitian, misalnya $Z$. zerumpet (lempuyang), C. purpurascens (temu blenyeh), $C$. aeruginosa (temu ireng), $C$. domestica (kunyit), C. heyneana (temu giring), B. pandurata (temu kunci), Z. officinale (jahe), C. zedoaria (temu putih blenyeh) dan Z. purpureum (bangle). Jenis-

Tabel 1. Lima jenis tumbuhan bawah dengan INP tertinggi yang terdapat dalam sistem agroforestri pekarangan dan tegalan.

\begin{tabular}{|c|c|c|c|c|c|}
\hline \multirow{2}{*}{ Zona } & \multirow{2}{*}{ No. } & \multicolumn{2}{|l|}{ Pekarangan } & \multicolumn{2}{|c|}{ Tegalan } \\
\hline & & Nama ilmiah & INP & Nama ilmiah & INP \\
\hline \multirow[t]{5}{*}{1} & 1 & Curcuma mangga & 55,495 & Curcuma mangga & 73,821 \\
\hline & 2 & Oplismenus burmanii & 23,810 & Synedrella nodiflora & 39,817 \\
\hline & 3 & Zingiber zerumpet & 21,245 & Eupatorium odoratum & 29,983 \\
\hline & 4 & Oxalis barrelieri & 14,835 & Adiantum sp. & 10,365 \\
\hline & 5 & Curcuma purpurascens & 13,187 & Biophytum sensitivum & 9,784 \\
\hline \multirow[t]{5}{*}{2} & 1 & Curcuma mangga & 60,154 & Curcuma mangga & 38,875 \\
\hline & 2 & Synedrella nodiflora & 23,674 & Colocasia esculenta & 24,195 \\
\hline & 3 & Boesenbergia pandurata & 17,577 & Oxalis barrelieri & 16,237 \\
\hline & 4 & Mimosa pudica & 11,400 & Elephantopus scaber & 15,973 \\
\hline & 5 & Oxalis barrelieri & 11,400 & Peperomia pellucida & 14,598 \\
\hline \multirow[t]{5}{*}{3} & 1 & Curcuma mangga & 46,080 & Curcuma mangga & 44,710 \\
\hline & 2 & Zingiber officinale & 20,568 & Amomum compactum & 25,988 \\
\hline & 3 & Oxalis barrelieri & 18,466 & Curcuma domestica & 17,342 \\
\hline & 4 & Boesenbergia pandurata & 15,341 & Alpina galangal & 16,653 \\
\hline & 5 & Peperomia pellucida & 13,295 & Canna edulis & 10,395 \\
\hline
\end{tabular}

Sumber: Data penelitian Hadi (2013). 
jenis tersebut dimanfaatkan oleh masyarakat sebagai bahan untuk bumbu, obat, dan untuk kepentingan ritual kebudayaan. Beberapa jenis ditanam sebagai salah satu sumber pendapatan, contohnya $Z$. officinale, B. pandurata, dan C. domestica. Namun banyak jenis tumbuh liar dan tidak terpelihara, namun keberadaannya tetap dijaga untuk kebutuhan ritual kebudayaan atau untuk pengobatan tradisional.

Famili Zingiberaceae banyak ditemukan di pekarangan zona 1 , hal ini dikarenakan masyarakat yang tinggal di zona 1 umumnya memiliki pekarangan yang lebih luas dibandingna pekarangan di zona 2 dan 3 yang umumnya memiliki lahan sempit dengan kondisi topografi miring, sehingga masyarakat lebih cenderung menanam jenis kayukayuan Di tegalan, famili Zingiberaceae juga ditemukan namun jumlahnya tidak banyak dikarenakan penanaman jenis tersebut membutuhkan pemeliharaan yang intensif, sedangkan jarak antara tempat tinggal dengan lahan tegalan biasanya jauh sehingga untuk mencapai optimalisasi produksi relatif sulit.

Pekarangan dan tegalan merupakan praktek agroforestri yang banyak diadopsi oleh masyarakat di Kabupaten Kulon Progo yang bertujuan untuk memenuhi kebutuhan hidup. Di dalam pekarangan setiap hari selalu ada aktivitas manusia termasuk hewan peliharaannya. Fungsi pekarangan antara lain sebagai pengaturan lingkungan, sumber pendapatan tidak rutin, untuk mencoba menanam jenis-jenis baru, untuk menampung berbagai jenis tumbuhan asli dan untuk keindahan. Berdasarkan pemanfaatan jenis-jenis di pekarangan, Stoen dkk. (2009) mengelompokkan tanaman dalam 8 (delapan) kelompok, yaitu untuk sayuran, ornamen, makanan, buah-buahan, bumbu, obat, bahan konstruksi dan lain-lain. Simon (2010) menyatakan bahwa jika pekarangan merupakan satu kesatuan dengan rumah tempat tinggal penduduk, maka tegalan terletak 'agak jauh' dari rumah. Selain jaraknya dari rumah pemiliknya, perbedaan pekarangan dan tegalan juga terletak pada pemanfaatan output. Di tegalan aktivitas manusia tersebut berkurang, disebabkan jaraknya cukup jauh dari rumah. Masyarakat pada umumnya mengusahakan tanah tegalan dalam bentuk hutan rakyat dengan pohon sebagai salah satu jenis yang banyak ditanam (Hani dan Suryanto, 2014), hasilnya berupa kayu atau buah untuk dijual.

Jenis tanaman berkayu yang terdapat di pekarangan dan tegalan disajikan dalam Tabel 2 . Pekarangan cenderung ditanami jenis-jenis penghasil buah-buahan seperti G. gnemon, A. heterophyllus, C. papaya, C. nucifera dan $D$. zibethinus, produk perkebunan contohnya T. cacao dan S. aromaticum yang merupakan komoditas yang dikembangkan di wilayah Kabupaten Kulon Progo. Selain itu juga ditanam jenis penghasil kayu misalnya $T$. grandis, S. mahogany dan $F$. molucana, jumlahnya lebih sedikit dibandingkan di tegalan dan berfungsi sebagai pagar. Untuk jenis yang ditanam di lahan tegalan umumnya adalah penghasil kayu dan pakan ternak yang tidak membutuhkan pemeliharaan intensif, hal ini karena jarak lahan tegalan dengan tempat tinggal pemilik lebih jauh.

Tabel 2. Jenis-jenis pohon yang terdapat pada lokasi penelitian

\begin{tabular}{|c|c|c|c|c|}
\hline \multirow{2}{*}{$\begin{array}{c}\text { Sistem } \\
\text { agroforestri }\end{array}$} & \multirow{2}{*}{$\begin{array}{c}\text { Zona } \\
1\end{array}$} & \multirow{2}{*}{$\begin{array}{c}\begin{array}{c}\text { Intensitas } \\
\text { naungan }(\%)\end{array} \\
87,78\end{array}$} & \multicolumn{2}{|c|}{ Jenis tanaman penghasil } \\
\hline & & & Kayu & $\begin{array}{l}\text { Tectona grandis, Swietenia mahogany, } \\
\text { Falcataria molucana }\end{array}$ \\
\hline & & \multirow{4}{*}{71,49} & Buah & Cocos nucifera, Gnetum gnemon \\
\hline & \multirow[t]{3}{*}{2} & & Kayu & T. grandis \\
\hline & & & Buah & $\begin{array}{l}\text { Artocarpus heterophyllus, C. nucifera, } \\
\text { Carica papaya, Musa sp., G. gnemon }\end{array}$ \\
\hline & & & Produksi perkebunan & $\begin{array}{l}\text { Theobroma cacao, Syzygium } \\
\text { aromaticum }\end{array}$ \\
\hline & \multirow[t]{4}{*}{3} & \multirow[t]{4}{*}{62,53} & Kayu & S. mahogany, T. grandis, $F$. molucana \\
\hline & & & Buah & A. heterophylla, C. nucifera \\
\hline & & & Pakan ternak & Leucaena leucocepala \\
\hline & & & Produksi perkebunan & $\begin{array}{l}\text { Theobroma cacao, Syzygium } \\
\text { aromaticum }\end{array}$ \\
\hline \multirow[t]{5}{*}{ Tegalan } & 1 & 73,77 & Kayu & $\begin{array}{l}\text { S. mahogany, T. grandis, Melaleuca } \\
\text { cajuputi, Eucalyptus sp. }\end{array}$ \\
\hline & \multirow[t]{2}{*}{2} & \multirow[t]{2}{*}{67,43} & Kayu & S. mahogany, T. grandis, $F$. molucana \\
\hline & & & Pakan ternak & $\begin{array}{l}\text { Gliricidia sepium, Calliandra, Manihot } \\
\text { glaziovii }\end{array}$ \\
\hline & \multirow[t]{2}{*}{3} & \multirow[t]{2}{*}{87,70} & Kayu & F. molucana, Hibiscus tiliaceus \\
\hline & & & Buah & $\begin{array}{l}\text { A. heterophylla, Durio zibethinus, Musa } \\
\text { sp., C. nucifera }\end{array}$ \\
\hline
\end{tabular}


Tabel 3. Jenis tumbuhan bawah yang dimanfaatkan masyarakat sebagai bahan obat

\begin{tabular}{|c|c|c|c|c|c|}
\hline \multirow{2}{*}{ No. } & \multicolumn{3}{|c|}{ Nama jenis } & \multicolumn{2}{|l|}{ Status } \\
\hline & Lokal & Ilmiah & Famili & Potensi & Ket. \\
\hline 1 & Blimbingan & O. barrelieri & Oxalidaceae & Obat batuk & Gulma \\
\hline 2 & Ganyong & C. edulis & Cannaceae & $\begin{array}{l}\text { Patinya untuk mengobati penyakit } \\
\text { lambung }\end{array}$ & Liar \\
\hline 3 & Krambilan & B. sensitivum & Oxalidaceae & Obat darah tinggi & Gulma \\
\hline 4 & Legetan & S. nodiflora & Asteraceae & Penambah stamina & Gulma \\
\hline 5 & Lempuyang & Z. zerumpet & Zingiberaceae & Obat sakit perut/mulas, demam & Liar \\
\hline 6 & Putri malu & M. pudica & Fabaceae & Obat asma & Gulma \\
\hline 7 & Suruhan & P. pellucida & Piperaceae & Obat asam urat & Gulma \\
\hline 8 & Tales & C. esculenta & Araceae & Untuk menarik racun/ duri & Liar \\
\hline 9 & Tapak liman & E. scaber & Asteraceae & $\begin{array}{l}\text { Obat darah tinggi, hepatitis, kembung, flu, } \\
\text { demam, amandel }\end{array}$ & Gulma \\
\hline 10 & Temu kunci & B. pandurata & Zingiberaceae & Obat cacing kremi & Liar \\
\hline 11 & Temu mangga & C. mangga & Zingiberaceae & Obat kanker, mual, perut mulas & Gulma \\
\hline 12 & Lengkuas & A. galangal & Zingiberaceae & $\begin{array}{l}\text { Obat panu, kurap, sakit gigi, kembung, } \\
\text { eksim, demam, radang telinga, bronchitis, } \\
\text { diare dan masuk angin, afrodisiak }\end{array}$ & Ditanam \\
\hline 13 & Kunyit & C. domestica & Zingiberaceae & $\begin{array}{l}\text { Untuk mendinginkan badan, } \\
\text { membersihkan, menghentikan pendarahan } \\
\text { dan mencegah penggumpalan darah, } \\
\text { sebagai obat anti gatal, anti septik dan anti } \\
\text { kejang serta mengurangi pembengkakan } \\
\text { selaput lendir mulut, mengobati bengkak } \\
\text { dan terkilir serta menyembuhkan hidung } \\
\text { yang tersumbat }\end{array}$ & Ditanam \\
\hline 14 & Kapulaga & A. compactum & Zingiberaceae & $\begin{array}{l}\text { Meningkatkan sirkulasi darah, mencegah } \\
\text { pembekuan darah, mencegah osteoporosis, } \\
\text { analgesic tradisional, antiinflamasi, } \\
\text { mengobati gusi bengkak, diuretik, } \\
\text { afrodisiak dan menghilangkan stress }\end{array}$ & Ditanam \\
\hline 15 & Jahe & Z. officinale & Zingiberaceae & $\begin{array}{l}\text { Menurunkan tekanan darah (hipertensi), } \\
\text { mencegah tersumbatnya pembuluh darah, } \\
\text { mencegah mual, membuat lambung } \\
\text { menjadi nyaman, meringankan kram perut } \\
\text { dan membantu mengeluarkan angin, } \\
\text { pereda rasa sakit yang alami dan dapat } \\
\text { meredakan nyeri rematik, sakit kepala, dan } \\
\text { migren, mengobati luka karena lecet, } \\
\text { ditikam benda tajam, terkena duri, jatuh, } \\
\text { serta gigitan ular, mengobati gatal karena } \\
\text { sengatan serangga }\end{array}$ & Ditanam \\
\hline 16 & Glirisidia & Glirisidia sp. & Fabaceae & Insektisida nabati & Liar \\
\hline 17 & Awar-awar & Ficus septic & Amaranthaceae & Alat untuk mengobati telinga & Gulma \\
\hline 18 & $\begin{array}{l}\text { Dandang } \\
\text { gendis }\end{array}$ & B. laevis & Rubiaceae & Obat ginjal, kencing batu & Gulma \\
\hline 19 & Garut & M. arundinaceae & Maranthaceae & $\begin{array}{l}\text { Patinya untuk mengobati penyakit } \\
\text { lambung, dan bedak untuk bayi (gabag) }\end{array}$ & Liar \\
\hline 20 & Patikan & E. hirta & Euphorbiaceae & Obat tetes mata & Gulma \\
\hline 21 & Petut kuda & S. jamaicensis & Verbenaceae & Obat darah tinggi & Gulma \\
\hline 22 & Pulutan & U. lobata & Malvaceae & Bobok/ param & Gulma \\
\hline 23 & Regedek & C. asiatica & Apiaceae & Penambah stamina, menjaga daya ingat & Liar \\
\hline 24 & $\begin{array}{l}\text { Semanggi } \\
\text { gunung }\end{array}$ & H. rotundifolia & Apiaceae & Obat batuk & Liar \\
\hline 25 & Sintrong & C. crepidiodes & Asteraceae & Penambah stamina & Gulma \\
\hline 26 & Tembelekan & L. camara & Verbenaceae & Obat gatal & Gulma \\
\hline 27 & Temu giring & C. heyneana & Zingiberaceae & Bahan luluran & Liar \\
\hline 28 & Temu ireng & C. aeruginosa & Zingiberaceae & Penambah nafsu makan & Liar \\
\hline 29 & $\begin{array}{l}\text { Timpuh } \\
\text { wiyung }\end{array}$ & E. sonchifolia & Asteraceae & Penambah stamina & Gulma \\
\hline
\end{tabular}

Sumber: Data penelitian Hadi (2013)

Berdasarkan jumlahnya, tanaman di pekarangan lebih banyak jenisnya dibandingkan dengan di tegalan. Masyarakat melakukan introduksi jenis dengan tujuan untuk memenuhi kebutuhan hidup mereka dan untuk melakukan uji coba penanaman jenis baru. Hal ini dilakukan untuk memudahkan pemeliharaan dan pengawasan terhadap tanaman tersebut. Namun demikian, 
komposisi jenis di pekarangan cenderung dipengaruhi oleh kebutuhan, pribadi, tradisi setempat, dan kondisi lingkungan, sehingga sifatnya sangat lokal.

\section{Pemanfaatan Tumbuhan Bawah Sebagai Bahan Obat}

Masyarakat di Kabupaten Kulon Progo masih banyak memanfaatkan berbagai jenis tumbuhan disekitarnya sebagai bahan pangan, bumbu, obat, pakan ternak, kayu bakar dan kayu untuk bangunan. Topografi yang berbukit-bukit dan aksesibilitas yang terbatas pada sarana dan prasarana kesehatan membuat masyarakat masih memanfaatkan tumbuhan sekitarnya sebagai bahan obat. Contohnya masyarakat di Desa Batu Ampar yang lokasinya berdekatan dengan kawasan hutan lindung Bukit Raja Mandara (Kabupaten Bengkulu Selatan) memanfaatkan 83 jenis tumbuhan, yaitu sebagai bahan makanan, obat-obatan, bahan bangunan, kayu bakar, pagar hidup, kerajinan tangan, pewarna dan racun (Wiryono dan Lipranto, 2013). Pada Tabel 3 disajikan informasi pemanfaatan tumbuhan bawah oleh masyarakat

Tumbuhan bawah yang berhasil diidentifikasi sebanyak 41 jenis (lampiran), 29 jenis di antaranya dimanfaatkan masyarakat sebagai bahan obat, penambah stamina dan insektisida. Untuk bahan obat, diantaranya untuk penyakit kulit, demam, batuk, lambung dan beberapa penyakit degeneratif seperti hipertensi, kanker, asam urat, asma, dan sebagainya. Beberapa hasil penelitian tanaman obat menyebutkan $C$ mangga (temu mangga) memiliki kemampuan menghambat pertumbuhan bakteri $S$. aureus (Hadi, 2003), gel ekstrak daun P. pellucida (sasaladahan atau suruhan) memiliki efek penyembuhan terhadap luka bakar (Mappa dkk., 2013) serta memiliki efek antiinflamasi, ekstrak akar M. pudica (putri malu) memiliki sifat anthelmintik terhadap Hymenolepis sp. (Candra dkk., 2008).

Cara pemanfaatan yang dilakukan masyarakat di pegunungan Menoreh masih sangat sederhana. Cara pertama adalah dimakan langsung atau direbus (sebagai lalapan). Contohnya adalah $S$. nodiflora untuk meningkatkan stamina, $B$. pandurata untuk mengobati cacing kremi biasanya dikunyah saja, dan E. scaber direbus daunnya kemudian dimakan untuk menurunkan tekanan darah tinggi. Cara kedua adalah dengan direbus dan airnya diminum. Contoh tanamannya adalah $B$. sensitivum untuk menurunkan tekanan darah tinggi, $P$. pellucida untuk mengobati asam urat direbus kemudian dimakan, $M$. pudica untuk obat asma. Cara ketiga dengan diambil saripatinya. Contohnya adalah $C$. edulis untuk mengobati maag, $C$. domestica, $C$. mangga dan beberapa jenis dari famili Zingiberaceae juga dimanfaatkan sari patinya. Cara keempat dengan dikeringkan daunnya kemudian diseduh seperti teh, contohnya $C$. asiatica yang bermanfaatn sebagai penambah stamina. $C$ asiatica sudah di produksi oleh salah satu kelompok tani dan telah dikirim ke beberapa daerah seperti Jakarta,Surabaya, beberapa kota di Kalimantan.

Beberapa jenis dari famili Zingiberaceae ditanam oleh masyarakat karena dimanfaatkan sebagai bumbu dapur dan sebagai sumber penghasilan. Contohnya kunyit, jenis ini tumbuh baik di bawah naungan atau tegakan hutan dengan intensitas cahaya matahari sekitar 70\% (Syahid dkk., 2012). Potensi lahan di bawah tegakan di Pulau Jawa cukup luas dengan tanaman utama jati dan sengon. Lahan di bawah tegakan merupakan lahan potensial untuk pertanaman kunyit yang akan memberikan tambahan penghasilan bagi petani. Hal tersebut sesuai dengan tujuan pengembangan agroforestri, yaitu tercapainya stabilitas ekologi (multijenis dan multistrata) dan kesinambungan ekonomi (multiproduk dan low input).

Pemanfaatan tumbuhan bawah sebagai obat yang selama ini hanya berdasarkan tradisi dan informasi turun temurun perlu diteliti secara ilmiah. Penelitian tersebut akan membantu menggali potensi alami jenis-jenis di bawah tegakan sehingga di masa yang akan datang dapat dikembangkan menjadi komoditas yang bernilai ekonomi tinggi untuk meningkatkan perekonomian masyarakat serta mendukung upaya konservasi tanah di pegunungan Menoreh, Kabupaten Kulon Progo.

\section{KESIMPULAN}

Keanekaragaman jenis tumbuhan bawah di pekarangan lebih tinggi dibandingkan di tegalan. Keanekaragaman jenis tumbuhan bawah berbanding lurus dengan ketinggian tempat, yaitu jumlah jenis di zona 1 lebih sedikit dibandingkan di zona 2 dan 3 .

Tumbuhan bawah yang berhasil diidentifikasi sebanyak 41 jenis, 28 jenis di antaranya dimanfaatkan masyarakat sebagai bahan obat dan 1 jenis sebagai bahan insektisida nabati. Untuk bahan obat antara lain untuk penyakit kulit, demam, batuk dan beberapa penyakit degeneratif seperti hipertensi, kanker, asam urat, asma dan sebagainya. Cara pemanfaatan yang dilakukan masih sederhana yaitu dengan dimakan langsung, direbus, dibuat teh dan diambil sari patinya.

Potensi tumbuhan bawah sebagai bahan obat dapat dikembangkan dalam pola agroforestri pekarangan dan tegalan sebagai bentuk diversifikasi dan domestikasi jenis yang pada akhirnya diharapkan mampu meningkatkan pendapatan masyarakat di perbukitan Menoreh. 


\section{UCAPAN TERIMAKASIH}

Penelitian ini didanai dengan dana penelitian dari Pusdiklat Kehutanan, Kementerian Kehutanan dan dana DPP Fakultas Kehutanan UGM tahun anggaran 2013 (No. 228/KS/2013) dengan peneliti utama sebagai penulis kedua.

\section{DAFTAR PUSTAKA}

Abdiyani, S., 2008. Keanekaragaman Jenis Tumbuhan Bawah Berkhasiat Obat di Dataran Tinggi Dieng. Jurnal Penelitian Hutan dan Konservasi Alam 5(1):79-92.

Candra, A.A., Ridwan, Y., dan Retnani, E.B., 2008. Potensi Anthelmintik Akar Tanaman Putri Malu (Mimosa pudica L.) Terhadap Hymenolepis Nana Pada Mencit. Media Peternakan, 31(1):29-35.

Djufri, 2010. Komposisi dan Keanekaragaman Tumbuhan Bawah pada Tegakan Akasia di Taman Nasional Baluran Jawa Timur. Jurnal Biologi Edukasi, 2(2):45-68.

Djufri, 2011. Pengaruh Kerapatan Akasia (Acacia nilotica)(L.) Willd. Ex. Del. Terhadap Komposisi dan Keanekaragaman Tumbuhan Bawah di Taman Nasional Baluran Jawa Timur. Jurnal Biologi Edukasi 3(1): 43-53.

Hadi, E.E.W., 2013. Tumbuhan Bawah Dominan Penghasil Bahan Obat Herbal Pada Sistem Agroforestri. Tesis Universitas Gadjah Mada, Yogyakarta.

Hani, A. dan Suryanto, P., 2014. Dinamika Agroforestry Tegalan di Perbukitan Menoreh, Kulon Progo, Daerah Istimewa Yogyakarta. Jurnal Penelitian Kehutanan Wallacea, 3(2):119-128.

Hilwan, I., Mulyana, D., dan Pananjung, W. G., 2013. Keanekaraaman Jenis Tumbuhan Bawah pada Tegakan Sengon Buto (Enterolobium cyclocarpum Griseb.) dan Trembesi (Samanea saman Merr.) di Lahan Pasca Tambang Batubara PT Kitadin, Embalut, Kutai Kartanagara, Kalimantan Timur. Jurnal Silvikultur Tropika, 4(1): 6-10.

Kandari, L.S., Phondani, P.C., Payal, K.C., Rao, K.S., and Maikhuri, R.K., 2012. Ethnobotanical Study towards Conservation of Medicinal and Aromatic Plants in Upper Catchments of Dhauli Ganga in the Central Himalaya. Journal of Mountain Science, 9:286-296.

Karina, S., 2014. Jenis Tumbuhan Berguna Pada Pekarangan Masyarakat Percampuran di Kelurahan Layana Indah Kecamatan Palu Timur Sulawesi Tengah. Biocelebes 8(2):1-12.
Kumar, B.M. dan Nair, P.K.R., 2004. The Enigma of Tropical Homegardens. Agroforestry System, 61: 153-152.

Kurniawan, A. dan Parikesit, 2008. Persebaran Jenis Pohon di Sepanjang Faktor Lingkungan di Cagar Alam Pananjung Pangandaran, Jawa Barat. Biodiversitas, 9(4):275-279.

Kusumedi, P. dan Jariyah, N.A., 2010. Analisis Finansial Pengelolaan Agroforestri Dengan Pola Sengon Kapulaga di Desa Tirip, Kecamatan Wadaslintang, Kabupaten Wonosobo. Jurnal Penelitian Sosial dan Ekonomi Kehutanan, 7(2):93-100.

Lubis, S.R., 2009. Keanekaragaman dan Pola Distribusi Tumbuhan Paku di Hutan Wisata Alam Taman Eden Kabupaten Toba Samosir Provinsi Sumatera Utara. Tesis Universitas Sumatera Utara, Medan.

Mappa, T., Edy, H.J., dan Kojong, N. 49 Formulasi Gel Ekstrak Daun Sasaladahan (Peperomia pellucida (L.) H.B.K.) dan Uji Efektivitasnya Terhadap Luka Bakar Pada Kelinci (Oryctolagus cuniculus). Pharmacon, 2(2):4955.

Nahdi, M.S., Marsono, D., Djohan, T.S., dan Baequni, M., 2014. Struktur Komunitas Tumbuhan dan Faktor Lingkungan di Lahan Kritis, Imogiri Yogyakarta. Jurnal Manusia dan Lingkungan, 21(1):67-74.

Rahayu, M. dan Prawiroatmodo, S., 2005. Keanekaragaman Tanaman Pekarangan dan Pemanfaatannya di Desa Lampeapi, Pulau Wawoni-Sulawesi Tenggara. Jurnal Teknologi Lingkungan, P3TL-BPPT 6(2):360-364.

Rina, D.N., Chairul, dan Solfiyeni, 2012. Komposisi dan Struktur Tanaman Pekarangan Dataran Tinggi di Nagari Alahan Panjang Kabupaten Solok. Jurnal Biologi Universitas Andalas, 1(2):144-149.

Setiawan, H. dan Qiptiyah, M., 2014. Kajian Etnobotani Masyarakat Adat Suku Moronene di Taman Nasional Rawa Aopa Watumohai. Jurnal Penelitian Kehutanan Wallacea, 3(2):107-117.

Simon, H., 2010. Dinamika Hutan Rakyat di Indonesia. Pustaka Pelajar, Yogyakarta

Stoen, M.A., Moe, S.R., Camargo, S.L. dan Ricalde, 2009. Homegardens Sustain Crop Diversity and Improve Farm Resilience in Candelaria Loxitha, Oaxaca, Mexico. Human Ecology, 37(1):55-77.

Syahid, S.F., Syukur, C., Kristina, N.N., dan Pitono, J., 2012. Adaptasi Delapan Nomor Harapan Kunyit (C. domestica Vahl.) Toleran Naungan. Buletin Ballittro, 23(2):115-124. 
Tjitrosoedirdjo, S., Utomo, I.H., dan Wiroatmodjo, J., 1984. Pengelolaan Gulma di Perkebunan. BIOTROP-Gramedia, Jakarta.

Wiryono dan Lipranto, 2013. The Diversity of Locally Useful Plants in Batu Ampar Village
Near Bukit Raja Mandara Protected Forest Area in South Bengkulu District. Jurnal Manusia dan Lingkungan, 20(2):119-128. 